Received 20.11.2014 Reviewed 10.02 .2015 Accepted 11.02.2015

A - study design

B - data collection

C - statistical analysis

D - data interpretation

E - manuscript preparation

F - literature search

\section{Application of CVM method in the evaluation of flood control and water and sewage management projects}

\author{
Tadeusz LIZIŃSKI ${ }^{1)}$ ABDF , Anna WRÓBLEWSKA ${ }^{1)}$ ABCDEF, \\ Krystyna RAUBA ${ }^{2)}$ ABCDEF
}

\footnotetext{
${ }^{1)}$ Institute of Technology and Life Science, Żuławy Research Centre, ul. Giermków 5, 82-300 Elblagg, e-mail: t.lizinski@itp. edu.pl, a.wroblewska@itp.edu.pl

${ }^{2)}$ Bialystok University of Technology, Faculty of Civil and Environmental Engineering, ul. Wiejska 45E, 13-351 Białystok, e-mail:k.rauba@pb.edu.pl
}

For citation: Liziński T., Wróblewska A., Rauba K. 2015. Application of CVM method in the evaluation of flood control and water and sewage management projects. Journal of Water and Land Development. No. 24 p. 41-49

\begin{abstract}
Traditional methods of economic evaluation of projects in the field of environmental protection do not reflect the full value of these projects. In particular, it doesn't take into account non-market effects that have an impact on the level of social welfare. The issue of valuation of natural resources and related services is also related to this problem. The evaluations and valuations of areas generally ignored the value of natural resources or take into account only the part which has the market value.

The article presents the results of study the economy of non-market goods using contingent valuation method. The first part of the results concerns the willingness to pay for improvement of safety sense from flood risk. The second part concerns willingness to pay for the use of municipal sewage treatment plants. The population living of the area of the Żuławy of Vistula delta valued their improvement of safety sense from flood risk of at more than twice the value of the compared to current expenditures incurred flood protection. The vast majority of respondents considered it reasonable protection of polder areas. Indicating simultaneously that in the reduction of flood risk allows possible resettlement and restoration polder parts. The majority of residents (98\%) agreed to the construction of wastewater treatment plants and were willing to pay for its construction and operation. The majority of respondents (especially those in middle age and older) found that the collective sewage development would contribute to improving the environment quality and thus the residents living standard. However, not all were willing to pay for the use of collective sewage collection and treatment. $18 \%$ of respondents did not want to pay an amount greater than the current charges for the sewage removal and treatment. In addition, the residents of the municipality cannot afford to pay, or believe that water supply and sanitation services should be free.
\end{abstract}

Key words: contingent valuation method, flood risk, sewage treatment, willingness to pay

\section{INTRODUCTION}

Contingent valuation method (CVM) is a method-speaking by interviews, the purpose of which is to reveal the respondents' preferences for willingness to pay for a precise improvement of environmental quality or availability of environmental goods or pay for the prevention of specific adverse changes in the environment. This method is one of methods allowing for non-market goods and services valuation. Travel cost method is also one of these methods and allows to determine the value of the tourist object based on its usefulness, expressed by willingness to pay [LIZIŃSKI, BUKOWSKI 2008]. 
Theoretical basis of CVM derived from the theory of rational consumer behavior. It is based on an ordered system of preferences consumed goods. In the classical theory of rational consumer behavior relates to market goods. The CVM method assumes that environmental goods are not subject to market also affect the level of social welfare. The method assumes a hypothetical market carried out by surveys [LIZIŃSKI 2010].

The first survey was conducted on consumer preferences in the 40s of the last century. They concerned a consumer purchases in the research conducted by the Federal Reserve USA [JUSTER 1966]. The first survey revealing consumer preferences regarding environmental goods led BowEN [1943], and CIRIACY-WANTRUP [1947]. In the 60s DAVIS [1963] presented the first application of this method to the environmental goods valuation, calling it both contingent valuation method (CVM). In 1980 contingent valuation method and other methods of research of the environment, i.e. travel cost method, hedonic price method and the methods of testing the effects of a dose-response effects was accepted in the United States. Current review of valuation studies conducted in many developing countries can be found in BILLER et al. [2006].

In Poland, the first contingent valuation method was used in studies relating to the protection of the Baltic Sea from excessive inflow of substances such as nitrates and phosphates. The obtained results showed how the Poles would be willing to pay to protect the Baltic Sea and the Baltic beaches from the negative effects of eutrophication [MARKOWSKA, ŻYLICZ 1999]. More recent studies using contingent valuation methods relate to, among others, willingness to pay for water quality improvements in one of the Polish lakes [CZAJKOVSKI, ŠČASNÝ 2010], willingness to pay for cleaner water in rivers and taps [MARKOWSKA 2004] or willingness to pay for improving the protection of Białowieża Forest [CZAJKOWSKI 2008]. Summaries of environment valuation researches, including the contingent valuation method, carried out mainly at the University of Warsaw, made ŻYLICZ [2000] and CZAJKOWSKI [2006; 2007].

Contingent valuation method is a method based on the interviews, through which the researcher attempts to extract information about the preferences of individuals by asking respondents about how highly value a given good or service. People are asked directly to specify how much they are willing to pay (WTP - Willingness To Pay) for a change in the availability of goods or services or for failure to change and/or how much they are willing to accept (WTA - Willingness To Accept) for failure to change or tolerate. The technique is referred to as "contingent" because the good or service is, in fact, will not necessarily be provided. The situation to which the respondent when determining the value is hypothetical and assumes that respondents behave in the same way as in the real market. Properly prepared questions and various forms of "auction", including questions about the maximum value of WTP, demanding answers "yes/no" can be applied. Then, in order to find the average value of WTP survey results are analyzed using econometric methods. CVM measures the strength of preference units with relation to public goods or mixed (public-private) using the ratio of their opinion on the value of cash. The main advantages of this method is given as:

1. The only method of determining the "nonuse" value, such as the value resulting from the existence of a unique environment or wildlife area;

2 . The obtained results suggest that the estimates obtained in a well-designed, well-conducted surveys turn out to be as good as the results obtained by other methods;

3. Design, analysis and interpretation of survey results have been improved with the development of the theory of random testing, benefit valuation theory in the field of public opinion research and computer analysis of data [GEORGIOU 1996].

Reliable results with this method can only be achieved through appropriately designed and wellconducted surveys. Various methodological problems that divide on problems connected with reliability, correctness and systematic errors have to be considered. Reliability is associated with the determination of the extent to which variation in response to questions about WTP (variance) may be associated with random error. The less the random specificity of the test, the less is its reliability, so that the average response resulting from the WTP has a little value. One way to avoid this error is the use of so-called replication tests (repeating the experiment on different samples in order to determine whether between the received variables is a correlation), however, this involves incurring additional costs. Systematic errors are related to the behavior of the respondent, which is dependent on its expectations of having to pay and deliver the goods. It is therefore necessary to construct the CVM in a way that respondents were deprived of motivation to give insincere answers. Systematic errors, which are exposed to this type of study are:

- good preparation of the respondent, the elimination of the conservative attitudes,

- elimination of the respondent difficulty in separating components of the environment from a physical or structural context which in effect overstates assessment,

- elimination of underrate or refusal to pay error,

- elimination of attitudes "good respondent" - trying to keep corresponding respectively to the anticipated expectations of the interviewer,

- the provision of high quality and the presentation of information on research and the item of valuation.

When examining the correctness of the application of the CVM is verified whether WTP estimate based on contingent valuation can be applied accu- 
rately to an object that we examine (construction), compared to the values obtained by the CVM with the "true" value of the good (criterion) at issue. The correctness of the valuation using this method also requires fulfilling the following recommendations:

- the questionnaire should include information enabling grouping and division of the collected data (age, sex, education, income, place of residence, the prior knowledge of the assessment);

- pilot study are needed to test the questionnaire and to obtain guidance on acceptable levels of listings;

- a large percentage of non-response disqualify study;

- direct interviews give the most reliable results;

- diagram of WTP questions is a recommended schedule format;

- to avoid the risk of overestimation of WTP;

- questions about the evaluation should be formulated in a manner reminiscent of a referendum on taxes (questions bipartite);

- respondents have to receive detailed information about the object of evaluation;

- respondents should be reminded about the existence of substitute goods, the alternative expenditure, limitation of household budget;

- errors resulting from the execution date of the test should be eliminated;

- option "no response" should be available to the respondent, as well as the adoption or rejection of the proposed proposals;

- the answer "yes" or "no" with respect to the proposed listings respondent should be asked for giving the reason of choice [GEORGIOU 1996].

The aim of this article is to present the application of the contingent valuation method to estimate expenditures on flood risk reduction and willingness to pay for wastewater treatment.

\section{RESEARCH METHODS}

Two research areas were determined. The first (Źuławy - the Vistula delta) concerned the willingness to pay for improvement of safety sense from flood risk. The second one (Podlasie Province) concerned the assessment of the social acceptability of the project, which is the implementation and operation of systems of collective sewage disposal and treatment in three selected municipalities.

Surveys were conducted on a group of more than 500 respondents, representatives of various professional and social groups inhabiting, working or studying in Żuławy the Vistula delta. Selection of respondents planned so that their group was representative of the population Żuławy. Surveys were carried out both at random and purposive sampling method.

Żuławy of Vistula delta cover an area of 170380 ha, of which 119960 ha are mechanical drainage area, while 50520 ha - gravitational drainage area. Status of the devices that determine the land use of mechanically drainage areas and to some extent determine the quality of agricultural production space of gravitational drainage areas, from which the water is drained by mechanically drainage areas is as follows: rivers $332 \mathrm{~km}$, canals - $1420.5 \mathrm{~km}$, embankments - 759.5 $\mathrm{km}$, pumping stations -105 pcs., hydraulic structures -20 pcs.

The aim of interview was to examine the opinions of the population on safety risk when living in flood areas, and alternative ways of farming in these areas. The question of the willingness to pay for the improvement of safety was preceded by an examination of opinion on the validity of the protection of the polder areas population and their resettlement and restoration of these areas. Were also investigated the importance of location factors, economic and cultural aspect of the respondents indicated the resettlement of the population. The questionnaire also indicates demographics containing such information about the respondent such as: sex, age, education, employment status, net monthly salary, place of residence [WRÓBLEWSKA 2014]. These data made it possible to introduce WTP depending on the age group and educational level.

The second area presents the results of a study to determine the willingness to pay for wastewater treatment. In 2008-2010 social acceptability of the project assessment was carried out, which is the implementation and operation of collective sewage disposal and treatment systems in three selected municipalities of the province of Podlasie, namely the municipalities Zbójna, Miastkowo and Dubicze Cerkiewne. Lack of collective systems area sewage collection and treatment on this area decided about selection of these municipalities, as objects of research. Using the willingness to pay (WTP) in three studied municipalities 321 questionnaires was performed by direct interview [RAUBA 2012]. Miastkowo municipality is located in the western part of the Podlasie region, in the basin of the river Narew with tributary of Ruż River. It consists of 23 villages. The area of the municipality is $114.84 \mathrm{~km}^{2}$. Miastkowo is inhabited by 4466 people. In the municipality there are no lakes or artificial reservoirs. Municipality Miastkowo has 98\% waterworks. This is very important because in the absence of a developed sewerage system there is a high risk of organic contaminants entering the water extracted from shallow dug wells. Water is drawn for the purpose of social - living in the absence of connections to bulk water supply system from such wells. The municipality does not have a sewerage system and wastewater treatment plant. Wastewater is collected in cesspools, and then exported to the holding tanks and is next pumped into cisterns and transported a few dozen kilometers away sewage treatment plant in Łomża [UG Miastkowo]. Zbójna municipality is located in the district of Łomża between the Narew, Pisa and Szkwa rivers. The commune included 19 villages. The municipality area is 18577 ha. Local inhabitants are supplied with water from the water supply system, water supply system-farm and dug 
wells. There is one shot of water, located in the village Zbójna in the municipality. In Zbójna only 3 are waterworks for 19 villages. A significant part of single-family homes is not connected to sewerage systems, due to the distributed nature of the settlement. Social and living wastewater, connected with the functioning of households, constitute $90-95 \%$ of the consumed water. Over $50 \%$ of the total number of farms has no sewerage system at all. The waste water is discharged into the ground and surface waters. The wastewater in the municipal area are collected in cesspools, and then exported to the tanker fleet, located a few dozen kilometers away sewage treatment plant in Łomża [UG Zbójna]. Municipality Dubicze Cerkiewne is located in the district of Hajnówka in the vicinity of the Białowieża Forest in the area of protected landscape. The commune includes 17 villages. The area of the municipality is $151 \mathrm{~km}^{2}$. Population of the municipality consists of 2089 people. Main source of supply of drinking water and economic needs are groundwater in the municipal area. Municipality Dubicze Cerkiewne is in 99\% waterworks, while the length of the sewerage system covers only $6 \%$ supported residents. [UG Dubicze Cerkiewne]. The questionnaire (WTP) was designed to reveal the preferences and willingness to pay of residents for the use of municipal sewage treatment plants. The survey was divided into three parts. The first part contained the initial questions which allowed the assessment of the knowledge level of the respondents on the issues of wastewater management in the municipality. The second part of the questionnaire contained questions about the methods and problems associated with the disposal of domestic wastewater, knowledge of the problems associated with pollution of waters of the municipality territory, as well as the respondents concern of the sewerage network development. The respondents were also asked about the cost of sewage disposal and the frequency of emptying septic tanks (where they are held by the respondent). Before asking a question, respondents were asked whether they agree to construction a sewage treatment plant, which could significantly reduce the pollutants (pollutions) in the wastewater discharged from the community. It was a WTP question (willingness to pay) and whether they would be willing to pay the amount proposed in the questionnaire. For those respondents who positively answered the question for a higher price was prepared for the water treatment plant. The first price was based on the average cost of wastewater in the municipality, the second takes into account operating costs, depreciation and profit waterworks and sewage. If the respondents did not choose any of the proposed prices, then they were able to propose the maximum amount they would be willing to pay for sewage as well as give the reason why did not choose any of the proposed prices.

The last part of the questionnaire concerned the personal data and the overall socio-economic charac- teristics of the respondents such as sex, age, income, education.

\section{RESEARCH RESULTS}

As a result of performed studies beyond the willingness to pay for the improvement of safety sense from flood risk respondents were also obtained an opinion on the validity of the protection of the polder areas population and their resettlement and restoration of these areas. Fig. 1. shows the distribution of responses on questions about the need to protect the population living in the polder's area.

The responses indicate that the vast majority of respondents $(85.4 \%)$ are in favor of the legitimacy of the protection of the population living in polder area. At the same time confirm that the resettlement of people from flood risk areas and their restoration are acceptable. The data presented in Fig. 2.

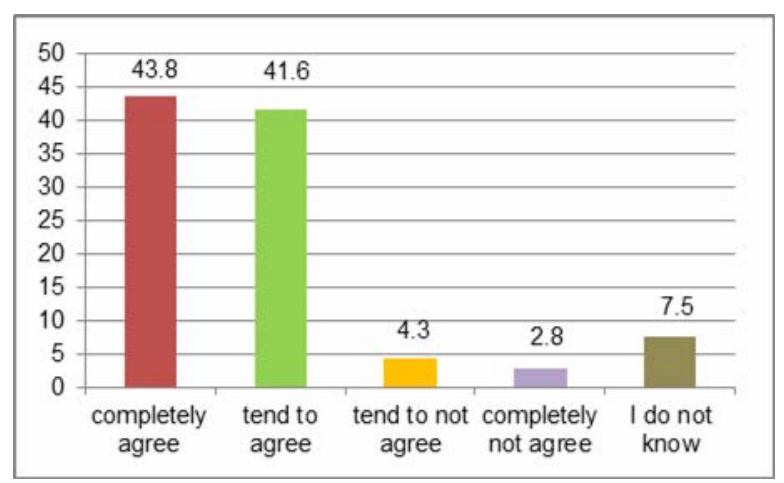

Fig. 1. Distribution of answers to the question whether it is appropriate to protect the population of the polder areas; source: own study

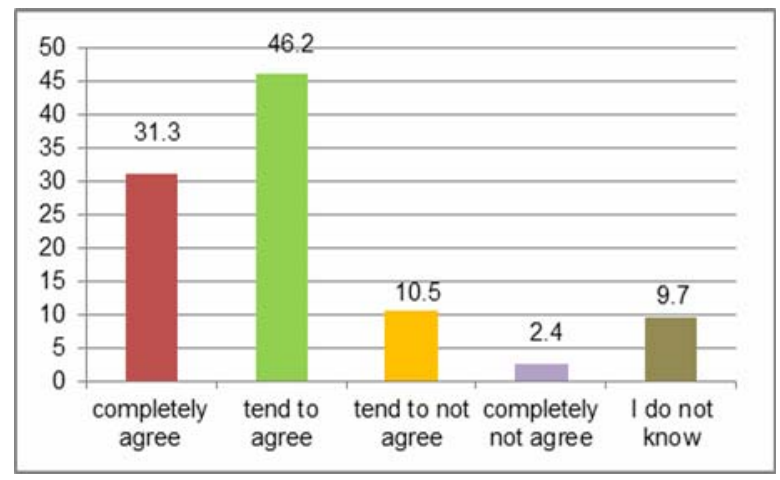

Fig. 2. Distribution of answers to the question of the legitimacy of the resettlement of people from flood risk areas and their restoration; source: own study

In the next stage of the study respondents were asked about the legitimacy of the resettlement of the population due to three types of factors: localization, economic and cultural. The distribution of responses is shown in Fig. 3, 4 and 5. 


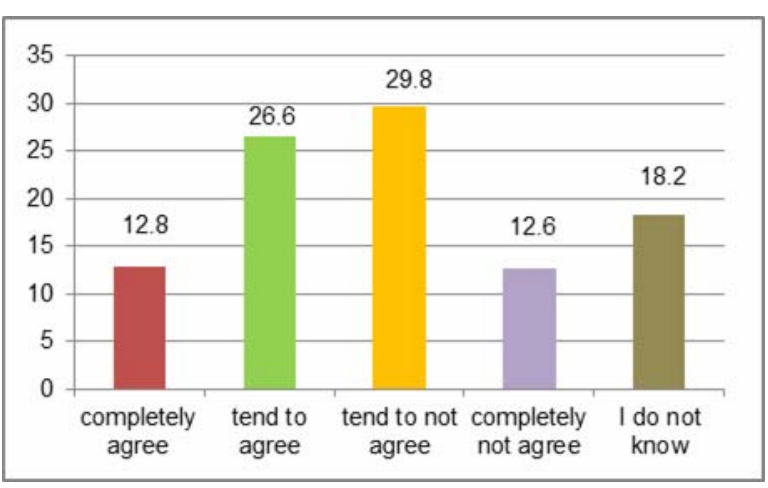

Fig. 3. The legitimacy of the resettlement of people due to localization factors; source: own study

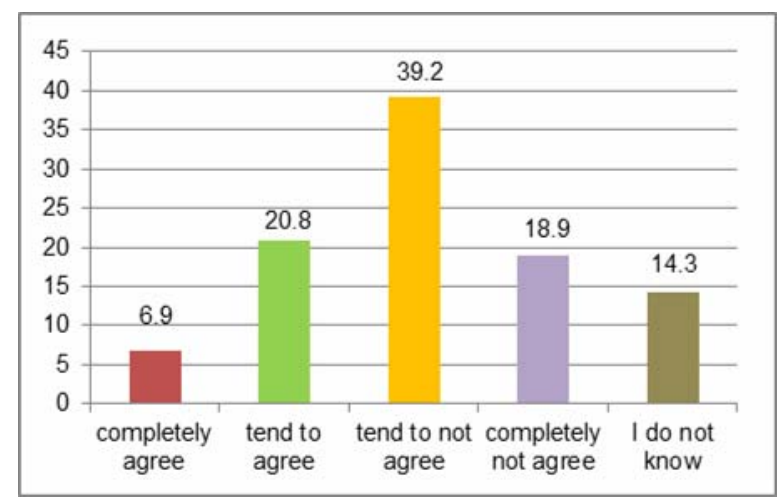

Fig. 4. The legitimacy of the resettlement of people due to economic factors; source: own study

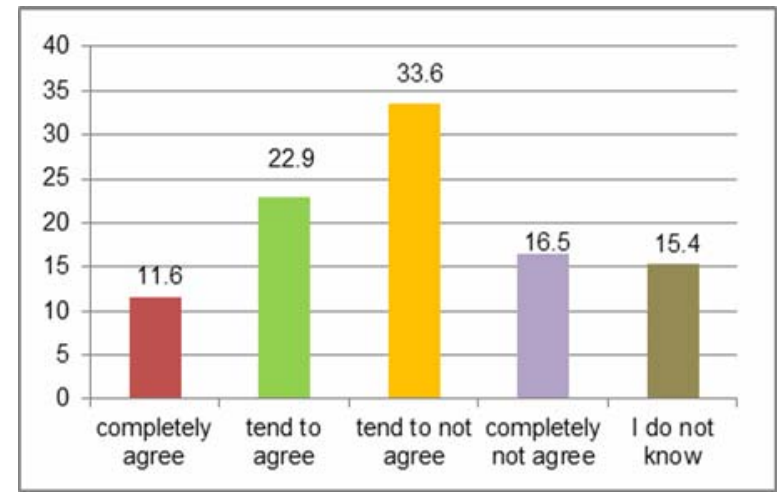

Fig. 5. The legitimacy of the resettlement of people due to cultural factors; source: own study

Localization factors, which characterize the area (eg. depression location) are not uniquely a condition of the necessity of displaced people. Nearly $40 \%$ of respondents think that it is reasonable, however, $42 \%$ disagree with this statement. It can be concluded that this is a neutral justification.

Different answers are given on the legitimacy of resettlement considering economic factors. $58 \%$ of respondents are not considered to be justified displacement of population due to economic factors. Thus, we can conclude that for respondents owned property and the agricultural and non-agricultural activity associated with particular market could determine the eventual resettlement.
A similar distribution of responses can be observed in the case of questions about the legitimacy of displaced people due to cultural factors. Nearly $60 \%$ of respondents are not considered to cultural factors (emotional relationship with a place, habit, tradition) justified the displacement of people from flood risk areas.

As a result of the survey were also obtained the amount estimated by the respondents which they were willing to pay (WTP) for improvement of security the sense from the flood risk. In accordance with the methodological recommendations of the $\mathrm{CV}$ method for measuring distributions WTP was calculated relative ages of the respondents, and education. Statistical information in the field of demography Żuławy of Vistula delta was used for further calculations. The area is populated by 250 thousand people [Programme 2010], where of below 21 years -14.7 thous., 21-30 years -48.3 thous., $31-40$ years -51.3 thous., $41-50$ years -39.2 thous., 51-60 years -44.0 thous., $61-70$ years -33.5 thous., $71-80$ years -17.6 thous., above 80 years -1.3 thous. people [GUS 2014]. For each age group was calculated declared willingness to pay for improvement of safety sense from flood risk and multiplied by the number of people in a given range. Obtained the same propensity to pay for the population Żuławy Vistula delta in the respective age groups. Declared amounts of willingness to pay for improvement of safety sense from flood risk in the age groups are shown in Fig. 6. Declared willingness to pay for improvement of safety sense from flood risk per year calculated according to the age structure was 386388202 PLN. Similarly willingness to pay for improvement of safety sense from flood risk according to education was calculated. The amounts declared in this category is shown in Fig. 7. Willingness to pay for improvement of safety sense from flood risk each year according to education amounted to 236659136 PLN.

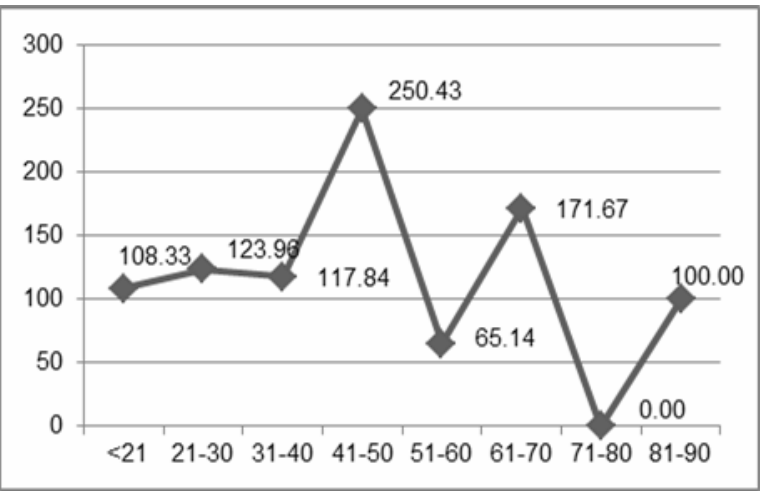

Fig. 6. Willingness to pay for improvement of safety sense from flood risk in the age groups (PLN); source: own study based on GUS [2014b]

The results were compared with expenditure incurred on investment projects in the field of flood protection in Żuławy of Vistula delta. In the years 2010-2015, they amounted to 915716741 PLN. 


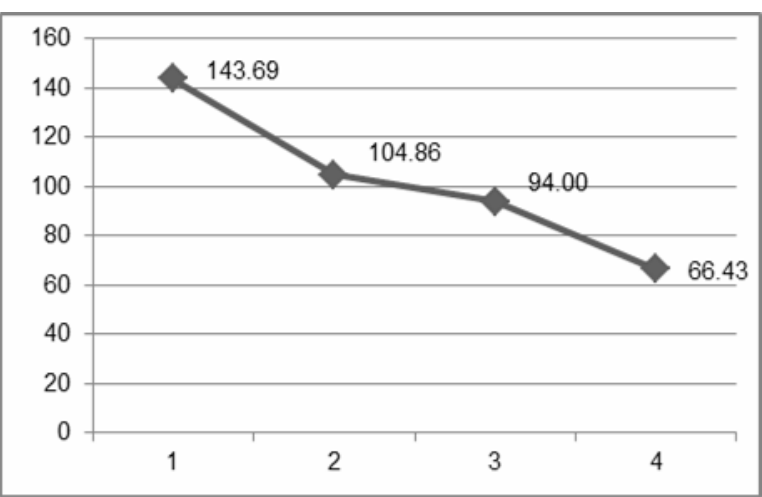

Fig. 7. Willingness to pay for improvement of safety sense from flood risk according to education (PLN); 1 - higher; 2 - post-secondary and secondary vocational; 3 - general secondary; 4 - vocational; source: own study based on GUS [2014a]

These costs include the implementation of the socalled. "Programme for Żuławy region" and other sources of financing. The operating costs of flood protection infrastructure during this period amounted to 75018143 PLN. The total costs of flood protection taking into account the investment and operating costs for the period of five years amounted to 933859816 PLN. The average annual cost of flood protection amounted to 163386772 PLN. Detailed data on spending and the size of WTP obtained are shown in Table 1.

Table 1. Investment and operating costs of flood protection in Żuławy of Vistula and willingness to pay for improvement of safety sense from flood risk according to age and education.

\begin{tabular}{|l|c|}
\hline \multicolumn{1}{|c|}{ Specification } & PLN \\
\hline Investment costs in years 2010-2015 & 741915716 \\
\hline $\begin{array}{l}\text { Operating costs of flood protection infrastructure In } \\
\text { years 2010-2015 }\end{array}$ & 75018143 \\
\hline Total costs of flood protection in years 2010-2015 & 816933859 \\
\hline Average costs of flood protection & 163386772 \\
\hline $\begin{array}{l}\text { WTP of Żuławy of Vistula delta population for } \\
\text { improvement of safety sense from flood risk ac- } \\
\text { cording to age annually }\end{array}$ & 386388202 \\
\hline $\begin{array}{l}\text { WTP of Żutawy of Vistula delta population for } \\
\text { improvement of safety sense from flood risk ac- } \\
\text { cording to education annually }\end{array}$ & 236659136 \\
\hline
\end{tabular}

Source: own study based on KZGW, RZGW Gdańsk [2014].

From the data presented in the table results that the willingness to pay of people living in the Żuławy of Vistula delta for improvement of safety sense from flood risk considered by age exceeds more than twice the value of the expenditure incurred on investments and maintenance of flood prevention infrastructure. WTP also considered by education exceeds expenditures for flood protection. This confirms the opinion of experts with a low level of current funding of the Vistula delta flood protection infrastructure.

Results of research concerning willingness to pay for wastewater treatment are shown below. In the whole $83 \%$ of group the respondents expressed their willingness to pay, while $17 \%$ didn't expressed. $86 \%$ of respondents showed willingness to pay others were opposed in the Zbójna municipality. 85\% of respondents have expressed willingness to pay for the construction of wastewater treatment facilities in the municipality Dubicze Cerkiewne, while $15 \%$ of respondents expressed no readiness. $78 \%$ of respondents showed willingness to pay in the municipality of Miastkowo however, while $22 \%$ of respondents were against.

The lowest proposed rate (excluding 0 PLN) in the municipality Zbójna was the amount of 2 PLN, which declared three persons, the highest rate of 12 PLN declared 4 persons. On average, the maximum amount was 6.14 PLN with a standard deviation of 2.55 PLN (with a median of 5,00 PLN). Approximately $25 \%$ of respondents suggested an amount equal to or less than 5 PLN, while $75 \%$ of the proposed amount equal to or less than 8 PLN. In turn, $25 \%$ of respondents said the amount above 8 PLN (Fig. 8).

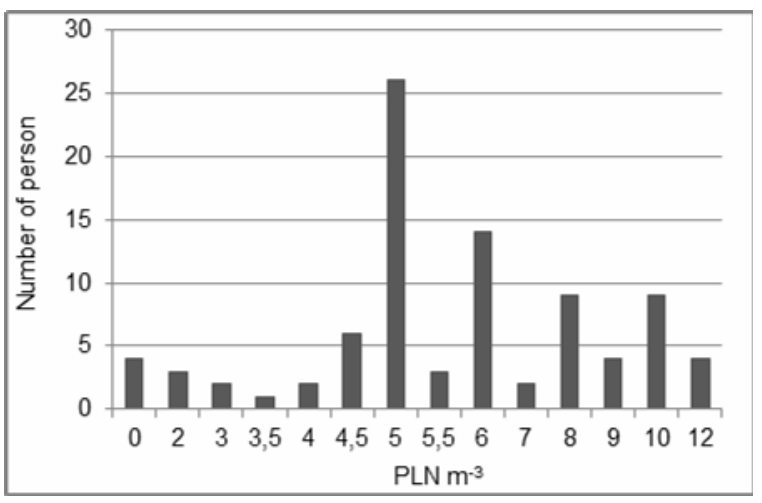

Fig. 8. Proposed amounts by inhabitants of Zbójna municipality; source: own study

The rate 5.5 PLN was a maximum average amount declared in the Dubicze Cerkiewne municipality with a standard deviation of 4.53 PLN (the median value was 4 PLN). The amount of 2 PLN was the lowest maximum rate (excluding 0 PLN), which declared one person, and 20 PLN was the highest proposed rate, declared by 4 respondents. Approximately $25 \%$ of respondents declared amount 3.18 PLN or less, while $75 \%$ of respondents reported an amount equal to or less than 8.86 PLN. In turn, $25 \%$ of respondents expressed a willingness to pay an amount higher than 8.86 PLN (Fig. 9).

One person declared lowest maximum amount (excluding 0 PLN) 1.50 PLN, when the highest proposed rate is 25 PLN, which was declared by 1 person in the municipality Miastkowo. On average, the maximum amount declared in the municipality was the rate of 7.57 PLN with a standard deviation of 5.38 PLN (the median value was 6 PLN). Approximately $25 \%$ of respondents declared amount 5.12 PLN or less, while $75 \%$ of respondents reported an amount equal to or less than 10 PLN. In turn, $25 \%$ of respon- 
dents expressed a willingness to pay an amount higher than 10 PLN (Fig. 10).

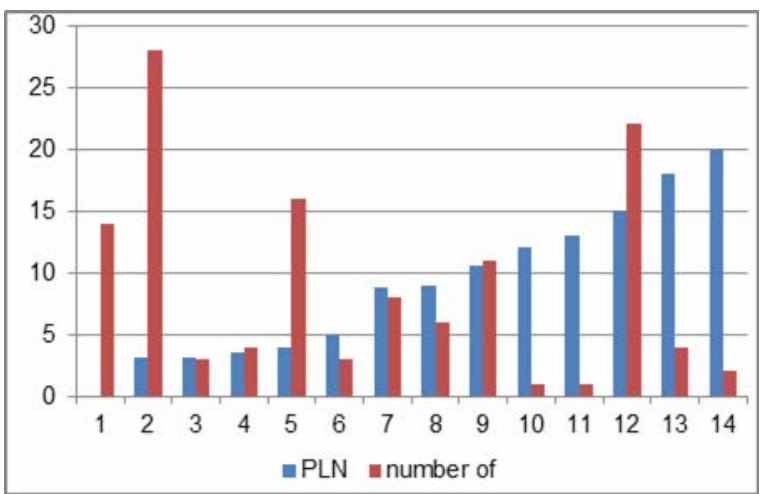

Fig. 9. Proposed amounts by inhabitants of Dubicze Cerkiewne municipality; source: own study

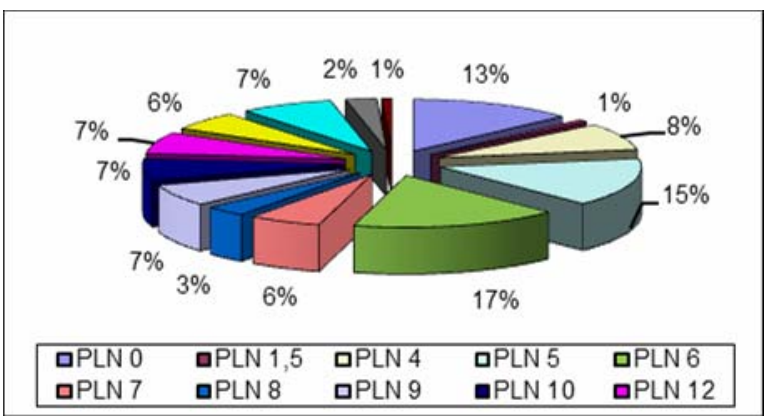

Fig. 10. Percent of respondents declaring individual amounts for collective wastewater treatment in Miastkowo municipality; source: own study

had no money, $6 \%$ of respondents were tired of Most people, as many as $30 \%$ of all respondents, thought that the disposal and purification of waste water service in their town should had for the money which had already paid, $11 \%$ of respondents said they paying for the case, which the community should take care of, $3 \%$ said that the quality of the environment would not improve, even if the wastewater treatment devices would be build, and $1 \%$ of respondents agreed that there is no need for wastewater treatment.

The study showed that middle-aged and the elderly people are willing to pay for the services of a collective wastewater treatment, while younger people do not declare their willingness to pay. This may be due to problems of young people migration from rural to urban. Young people want to move to bigger cities or abroad in order to find a better job, and older people would like to have solved the problems of wastewater treatment in their area. Perhaps older people have greater savings. In addition, unemployment is higher among young people, especially in this part of the Polish. There was no significant difference in the declared amounts taking into account sex, age and education of the municipality inhabitants.

However, regardless of age, educational level and income residents surveyed municipalities declare their willingness to pay for the use of collective wastewater treatment services as an essential element of environmental protection in the area of the municipality.

Studies conducted in the abovementioned municipalities showed that most residents agreed to the construction of municipal sewage treatment plants and were willing to finance its construction and operation. Construction and operation of such a system should contribute to improving the quality of surface and groundwater water in the studied communities and allow for the decommissioning of septic tanks and environmentally damaging transport of the sewage tanker fleet. This will create a better environment for the development of tourism in the areas surveyed municipalities.

\section{SUMMARY}

Traditional methods of economic evaluation of projects in the sphere of environmental protection does not reflect the full value of these projects. In particular, it does not take into account the non-market effects so-called externalities that have an impact on the level of social welfare. The issue of natural resources and related services valuation also is associated with this problem. The evaluations and valuations area generally ignored the value of natural resources or take into account only the part which has the market value.

The implementation of the sustainable development concept both at local, regional as well as national and community requires a extension the existing evaluation methods of projects in the sphere of environmental protection including investment projects and natural resources valuation having regard to their value in the micro and macroeconomic account.

Contingent valuation method (CVM) may be one of the methods useful in achieving good results in analyzing of flood risk and willingness to pay for environmental goods. In the results of the studies using a WTP procedure obtained data on the basis of which it can be concluded that the population living of the area of the Żuławy of Vistula delta valued their improvement of safety sense from flood risk of at more than twice the value of the compared to current expenditures incurred flood protection.

Research has shown that the vast majority of respondents considered it reasonable protection of polder areas. It also indicates that in the reduction of flood risk community of Żuławy of Vistula delta region allows possible resettlement and restoration polder parts. Larger limits for these actions result from economic reasons than localization or cultural.

WTP was also used in the examination of social acceptability of the project, which is the implementation and operation of collective sewage disposal and treatment systems in three selected municipalities of the Podlasie province, namely Miastkowo, Zbójna and Dubicze Cerkiewne. The collected data allowed to determine how the local community were willing to 
pay for improving the quality of water resources and for the use of the collective wastewater treatment service.

Studies conducted in the abovementioned municipalities have shown that the majority of residents $(98 \%)$ agreed to the construction of wastewater treatment plants and were willing to pay for its construction and operation. Because in the whole group, as many as $83 \%$ of respondents expressed a willingness to pay, while only $18 \%$ expressed no such readiness. The greatest willingness to pay (about 86\%) showed municipality Zbójna and Dubicze Cerkiewne, the smallest municipality Miastkowo $-78 \%$ of respondents. In addition, the study showed that residents of all three communities declared large amounts for the construction of wastewater treatment facilities. $75 \%$ of respondents said the amount of about 8 PLN, while above this amount declaration showed $25 \%$ of respondents in the Dubicze Cerkiewne and Zbójna municipality. However, $75 \%$ of respondents said the amount of about $10 \mathrm{PLN}$, while $25 \%$ of respondents suggested an amount higher than 10 PLN (up to 25 PLN) in the Miastkowo municipality.

The majority of respondents (especially those in middle age and older) found that the collective sewage development would contribute to improving the environment quality and thus the residents living standard.

However, not all were willing to pay for the use of collective sewage collection and treatment. $18 \%$ of respondents did not want to pay an amount greater than the current charges for the sewage removal and treatment. In addition, the residents of the municipality cannot afford to pay, or believe that water supply and sanitation services should be free.

\section{REFERENCES}

Biller D., Rogge K., Ruta G. 2006. The use of contingent valuation in developing countries. A quantitative analysis. In: Handbook on contingent valuation. Ed. A. Albertini, J.R. Kahn. Cheltenham. Edward Elgar Publishing. ISBN 9781840642087 pp. 448 .

BowEN H.R. 1943. The interpretation of voting in the allocation of economic resources. Quarterly Journal of Economics. No 58 p. 27-48.

CiriaCy-WantruP S.V. 1947. Capital returns from soilconservation practices. Journal of Farm Economics. No 29 p. $1181-1196$.

Council Regulation (EC) No 1260/1999 of 21 June 1999 laying down general provisions on the Structural Funds [online]. [Access 20.11.2014]. Available at: http://eurlex.europa.eu/legal-content/EN/TXT/PDF/?uri=CELEX: 31999R1260 \&rid $=5$

CZAJKOWSKI M. 2006. Polskie badania wyceny dóbr środowiskowych jako przykład międzynarodowej współpracy i zastosowania najnowocześniejszych osiagnięć nauki. W: Konferencja Młodych Naukowców: Współczesne zjawiska $\mathrm{w}$ gospodarce pt. Teoria a rzeczywistość [Polish study of environmental goods valuation as an example of international cooperation and the application of advanced scientific achievements. In: Young Researchers Confer- ence: Contemporary Occurrence in the Economy en. Theory and Reality] Torun. UMK.

CZAJKOWSKI M. 2007. Jak podejmować racjonalne decyzje dotyczące środowiska? Przykłady aplikacji badań wyceny dóbr środowiskowych w Polsce. W: Uwarunkowania rozwoju społeczno-gospodarczego Polski. [How to make rational decisions about the environment? Examples of the application of environmental goods valuation studies in Poland. In: Determinants of socio-economic development in Poland]. Ed. A.P. Balcerzak, D. Górecka. Toruń. Wydaw. Adam Marszałek p. 209-221.

CZAJKOWSKI M. 2008. Nośniki wartości dóbr środowiskowych [Media of environmental goods value]. $\mathrm{PhD}$ Thesis. Warszawa. UW pp. 302.

CZAJKOWSKI M., ŠČASNÝ M. 2010. Study on benefit transfer in an international setting. How to improve welfare estimates in the case of the countries' income heterogeneity? Ecological Economics. No 69 (12) p. 2409-2416.

DAVIS R.K. 1963. The value of outdoor recreation: an economic study of the maine woods. PhD Thesis. Harvard University. USA.

EC 2008. Guide to costbenefit analysis of investment projects. Structural Funds, Cohesion Fund and Instrument for Pre-Accession pp. 257.

Georgiou S. 1996. Metody wyceny warunkowej. W: Ekonomiczna wycena środowiska przyrodniczego [Contingent valuation method. In: Economic valuation of the natural environment]. Ed. G. Anderson, J. Śleszyński. Białystok. Wydaw. Ekon. Środ. p. 120-146.

GUS 2014a. Aktywność ekonomiczna ludności Polski. II kwartał 2014 [Labour force survey in Poland]. Warszawa ISSN $1425-7890$ pp. 131.

GUS 2014b. Ludność. Stan i struktura w przekroju terytorialnym. Stan w dniu 30 VI 2014 [Population in Poland. Size i structure in territorial division. As of June, 30, 2014]. Warszawa. ISSN 1734-6118 pp. 121.

JUSTER F.T. 1966. Consumer buying intentions and purchase probability: an experiment in survey design. Journal of the American Statistical Association. No 61 p. 658-696.

KZGW, RZGW Gdańsk 2014. Program „Kompleksowe zabezpieczenie przeciwpowodziowe Żuław - do roku 2030" zwany Programem Żuławskim - 2030. Plan działań dla etapu II (2014-2020) [Programme „Comprehensive flood protecion in Żuławy till 2030" called Żuławy Programme - 2030]. Gdańsk pp. 85.

LIZIŃSKI T. 2010. Podstawy ekonomii środowiska i zarządzania środowiskiem [Fundamentals of environmental economics and management]. Elblag. Wydaw. PWSZ. ISBN 8392731530 pp. 260.

LIZIŃSKI T., BUKOWSKI M. 2008. An assessment of the tourist value of the Elblag Canal. Journal of Water and Land Development. No 12 p. 37-48.

MarkowSKA A. 2004. Koszty i korzyści wdrożenia w Polsce dyrektywy 91/271/EWG w sprawie oczyszczania ścieków komunalnych [The costs and benefits of the implementing in Poland Directive 91/271/EEC concerning urban waste-water treatment]. $\mathrm{PhD}$ Thesis. Warszawa. UW.

MARKOWSKA A., ŻYLICZ T. 1999. Costing an international public good: The case of the Baltic sea. Ecological Economics. No 30 p. 301-316.

RAUBA K. 2012. Społeczna akceptowalność spełnienia zasady zwrotu kosztów usługi zbiorowego oczyszczania ścieków na obszarach wiejskich [Social acceptability meeting of cost recovery basis for collective wastewater treatment services in rural areas]. Handel Wewnętrzny. $\mathrm{Nr}$ spec. lipiec-sierpień. T. 2 p. 258-266. 
WRÓBLEWSKA A. 2014. Wartościowanie dóbr środowiskowych w świetle badań ankietowych według metody wyceny warunkowej [Evaluation of environment al goods in survey studies]. Woda-Środowisko-Obszary Wiejskie. T. 14. Z. 2 (46) p. 155-171.

UG Miastkowo [online]. [Access: 12.01.2010]. Available at: www.miastkowo.pl
UG Zbójna [online]. [Access: 12.01.2010]. Available at: www.zbojna.powiatlomzynski.pl

UG Dubicze Cerkiewne [online]. [Access: 12.01.2010] Available at: www.dubicze-cerkiewne.pl

ŻYLICZ T. 2000. Costing nature in a transition economy. Case studies in Poland. Chelthenham. Edward Elgar Publ. ISBN 978-1858984933 pp. 192.

\section{Tadeusz LIZIŃSKI, Anna WRÓBLEWSKA, Krystyna RAUBA}

\section{Zastosowanie metody wyceny warunkowej (CVM) w ocenie przedsięwzięć z zakresu ochrony przeciwpowodziowej i gospodarki wodno-ściekowej}

Słowa kluczowe: metoda wyceny warunkowej, odprowadzenie ścieków, ryzyko powodziowe, skłonność do zaplaty

\section{STRESZCZENIE}

Tradycyjne metody oceny ekonomicznej przedsięwzięć w sferze ochrony środowiska nie oddają pełnej wartości tych przedsięwzięć. W szczególności nie uwzględniają efektów pozarynkowych mających wpływ na poziom dobrobytu społecznego. Z tym problemem wiąże się również kwestia wyceny zasobów przyrodniczych i usług z nią związanych. W ocenach i wycenach obszarowych pomija się na ogół wartości zasobów przyrodniczych lub uwzględnia się tylko tę ich część, która ma wartość rynkową.

W artykule przedstawiono wyniki badań z wykorzystaniem metody wyceny warunkowej, która należy do metod wyceny dóbr i usług nierynkowych. Posłużono się wynikami badań dotyczących przedsięwzięć z zakresu gospodarki wodnej. Pierwsza część wyników dotyczy skłonności do zapłaty za poprawę poczucia bezpieczeństwa z tytułu zagrożenia powodzią, druga - skłonności do zapłaty za odprowadzenie ścieków. Ludność zamieszkująca obszar Żuław Wiślanych wycenia swoje bezpieczeństwo przeciwpowodziowe na poziomie ponad 2-krotnie wyższym w stosunku do obecnie ponoszonych nakładów na ochronę przeciwpowodziową. Zdecydowana większość ankietowanych uważa również za zasadne ochronę obszarów polderowych, wskazując jednocześnie, iż w ograniczaniu ryzyka powodziowego dopuszcza ewentualne przesiedlenie i renaturyzację części polderowych. Większość mieszkańców (98\%) wyraża zgodę na budowę oczyszczalni ścieków oraz jest skłonna do finansowania jej budowy i eksploatacji. Większość badanych osób uważała, że rozwój zbiorowego odprowadzania ścieków przyczyni się do poprawy jakości środowiska, a tym samym poprawy standardu życia mieszkańców. Nie wszyscy jednak są skłonni do zapłacenia za korzystanie ze zbiorowego odprowadzania i oczyszczania ścieków - 18\% respondentów nie chce płacić kwot wyższych niż dotychczas za usuwanie i oczyszczanie ścieków. Poza tym mieszkańców gminy albo nie stać na zapłacenie, albo też uważają, że usługi wodociągowo-kanalizacyjne powinny być bezpłatne. 